\title{
Cognitive profiles of patients with early detected and treated congenital hypothyroidism
}

\author{
María L. Pardo Campos, M.D. ${ }^{a}$, Mariel Musso, M.D. ${ }^{b}$, Ana Keselman, M.D. ${ }^{c}$, \\ Laura Gruñeiro, M.D. ', Ignacio Bergadá, M.D. ${ }^{c}$ and Ana Chiesa, M.D.c
}

\section{ABSTRACT}

Introduction. Children with congenital hypothyroidism $(\mathrm{CH})$ detected by newborn screening and adequately treated may have mild cognitive deficits.

Objectives. To assess the intelligence quotient of children with $\mathrm{CH}$ and identify the presence of specific cognitive deficits.

a. Universidad Católica Argentina, School of Psychology and Educational Psychology. Fundación de Endocrinología Infantil, Argentina.

b. Interdisciplinary Center for Research in Mathematical and Experimental Psychology (Centro Interdisciplinario de Investigaciones en Psicología Matemática y Experimental, CIIPME) - National Scientific and Technical Research Council (Consejo Nacional de Investigaciones Científicas y Técnicas, CONICET). Universidad Argentina de la Empresa, Argentina.

c. Hospital de Niños Ricardo Gutiérrez. Fundación de Endocrinología Infantil, Argentina.

E-mail address

María L. Pardo

Campos, M.D.:

mlpardocampos@

gmail.com

Funding:

None.

Conflict of interest:

None.

Received: 6-7-2016

Accepted: 9-12-2016

\section{INTRODUCTION}

Prim a r congen it a 1 hypothyroidism $(\mathrm{CH})$ is defined as the condition resulting from thyroid hormone deficiency present at birth and caused by abnormalities in thyroid gland formation or function. ${ }^{1}$ Thyroid hormones are essential since the early stages of life for the development of the central nervous system (CNS) because they play a role in neurogenesis, neuronal migration, neuronal axon and dendrite development, synaptogenesis, myelination, and specific neurotransmitter regulation. ${ }^{2}$ Thyroid hormones act as a "biological clock" that organizes and coordinates the processes defining CNS area differentiation. The absence of thyroid hormones in the perinatal period may predominately affect the cerebellum, the hippocampus, the frontal lobes, and the visual cortex. ${ }^{3}$

Since their mass implementation in the $20^{\text {th }}$ century, newborn screening programs have become one of the most widely accepted aspects of present pediatric preventive medicine, and are basically targeted at the early identification and treatment of children with hypothyroidism, which is mostly unapparent at birth. There is extensive written evidence on the importance of early newborn screening programs and the initiation of a timely and adequate treatment to prevent any mental retardation inherent to the untreated disease. ${ }^{4}$

The goal of screening programs is to allow affected subjects to achieve, by means of an early and adequate detection and treatment, their highest growth and cognitive development potential. For this reason, children in whom the condition has been detected 
are periodically monitored, and there is evidence that most subjects adequately identified using this strategy have a normal cognitive development.

However, at present, it has been proposed that early detection and treatment -which prevent severe mental disability- may not rule out certain mild cognitive deficits associated with the impact of the disease in itself, which may persist even once the patient has undergone detection and timely treatment.

Some examples include attention deficits, ${ }^{2,3,5-11}$ memory deficits, ${ }^{3,5-7,9-13}$ cognitive flexibility and working memory deficits, $6,14,15$ problems with visuospatial skills, ${ }^{3,5-7,9,12,13,15-17}$ and difficulties with processing speed and reaction times. . $, 6,11^{-1}$

However, no studies have been conducted in our population to analyze mild cognitive deficits that may be potentially present in $\mathrm{CH}$.

This study proposed to assess the intelligence quotient in this child population and identify specific cognitive deficits.

\section{POPULATION AND METHODS}

This was a descriptive, comparative study with an ex post facto, cross-sectional, and prospective design conducted in the 2010-2011 period in children with $\mathrm{CH}$ (group G1) aged 9-10 and children without $\mathrm{CH}$ in the same age range that were included as the control group (G2).

Age for assessment was selected to examine executive functions because the frontal lobes and, specifically, the prefrontal areas, involved in selfregulation reach their maximum development between 6 and 9 years old. It was also established to avoid the confounding effect caused by puberty, which leads to a certain imbalance in the brain, cognitive, and motivational circuit, and results in vulnerability due to the increased impulsiveness and risk-taking behaviors typical of this stage.

The sample size was estimated at 60 children in each group to obtain a $95 \%$ confidence level, an $80 \%$ statistical power, and a $5 \%$ absolute accuracy on both sides of the proportion (non-probability accidental sample).

G1 subjects were recruited among 200 children with $\mathrm{CH}$ seen at the Department of Endocrinology of Hospital de Niños Ricardo Gutiérrez of the Autonomous City of Buenos Aires (Argentina). Within this population, an intentional sample that met the following inclusion criteria was selected: a) having an early $\mathrm{CH}$ diagnosis ( $<30$ days old); b) having received an early and adequate treatment; and c) receiving follow-up care with successful adherence to medical checkups and with adequate periodic biochemical controls that confirm such adherence.

G2 subjects were recruited from private and public schools from Greater Buenos Aires and the Autonomous City of Buenos Aires. School authorities were asked for permission in advance, and parents gave their consent.

The sample was selected in 2010, and data were collected between 2010 and 2011.

The inclusion criteria for both groups were that children had no concurrent disease, were attending a private or public school in a single shift in the Autonomous City of Buenos Aires and Greater Buenos Aires, and whose parents had at least completed secondary education.

The single shift school and the parental level of education criteria were implemented to homogenize environmental stimulation factors that may influence on cognitive development.

All children were assessed using the following battery of psychometric and neuropsychological tests: the Wechsler Intelligence Scale for Children, third edition (WISC III) $;^{18}$ the Rey complex figure test (copying and drawing from memory a complex geometric figure) ${ }_{i}^{19}$ the WoodcockMuñoz revised test (retention and recall tasks of short- and long-term verbal stimuli, and graphic stimulus cancellation tasks with execution time) ${ }^{20}$ the Conners Continuous Performance Test II (CPT II) (stimulus cancellation tasks with different presentation times); ${ }^{21}$ the Illinois Test of Psycholinguistic Abilities (ITPA) (words to recall based on semantic criteria), ${ }^{22}$ the verbal fluency test (words to recall based on phonological criteria), ${ }^{23}$ the Knox Cube test (visuospatial stimulus repetition task) ${ }_{;}^{24}$ the Trail Making Test (continuous processing of two simultaneous stimulus) ${ }_{i}^{25}$ the differences in perception of faces test (cancellation task based on visual analysis and discrimination), ${ }^{26}$ the 5 digit test (stimulus selection activity with resistance to interference from secondary stimuli). ${ }^{27}$

The tests were administered during four individual outpatient interviews inside the office. Children in the control group were interviewed inside a classroom decorated to look like a doctor's office. Individual results were delivered in written during a feedback interview. Also during this interview, guidelines were provided, if necessary.

The study was approved by the Ethics, Teaching, and Research Committee of Hospital de Niños Ricardo Gutiérrez. A written informed consent was obtained from the parents of all study children, and children gave their oral assent 
for study participation.

The effect of $\mathrm{CH}$ on studied cognitive functions and differences from the control group were assessed using Student's $t$ tests for independent samples. The effect size was analyzed for all results using the partial Eta squared $\left(\eta p^{2}\right)$ statistics. Given that multiple tests were administered (compared outcome measures), analysis was completed using Bonferroni's correction; an adjusted significance level of 0.00227 was considered significant for the null hypotheses of cognitive functions. The Statistical Package for Social Sciences (SPSS), version 11.5, was used for statistical data processing.

\section{RESULTS}

The sample was selected using a purposive method; G1 was made up of 60 children (girls: $57 \%$ ) aged $9.4 \pm 0.5$ years old, and G2 included 60 children without $\mathrm{CH}$ (girls: $55 \%$ ) aged $9.5 \pm 0.5$ years old.

All G1 children had been diagnosed and treated before 30 days old. Their L-thyroxine dose was always $10-15 \mu \mathrm{g} / \mathrm{kg} /$ day. Athyreotic hypothyroidism was diagnosed in 22 children, and an ectopic thyroid gland was observed in 16.

All assessed children were attending the corresponding school grade for their age, none had repeated the school year, and all completed the test battery.

Children in both groups showed an average normal total intelligence quotient (TIQ), verbal intelligence quotient (VIQ), and performance intelligence quotient (PIQ). TIQ of G1: $94 \pm 8$ versus TIQ of G2: $102 \pm 7$. VIQ of G1: $100 \pm 9$ versus VIQ of G2: $104 \pm 8$. PIQ of G1: $85 \pm 7$ versus PIQ of G2: $98 \pm 8$. Significant differences were observed between both groups in terms of TIQ and PIQ with a small and moderate effect size, respectively. No significant differences were observed in relation to VIQ (Table 1).

The assessment of cognitive function in both groups is described in Table 2.

G1 children showed a decreased cognitive profile in terms of processing speed, reaction times, and long-term semantic memory, with a moderate effect size. The performance in focused, divided, and sustained attention, visuoconstruction, and cognitive flexibility was also reduced in relation to children without $\mathrm{CH}$, but the effect size was small. No significant differences were observed in tasks related to the attention span with auditory and visuospatial stimuli or in the visual processing tests.

\section{DISCUSSION}

Our results confirm that children with congenital hypothyroidism detected at birth and adequately treated during childhood have a normal intelligence quotient. However, consistent with previous publications, we observed in these children a significant difference in the TIQ exclusively at the expense of the PIQ, and the same performance in the verbal area. ${ }^{28,29}$

In terms of performance, children with hypothyroidism had a significantly poorer performance in terms of processing speed, reaction times, attention, cognitive flexibility, visuoconstruction, and long-term memory.

In relation to processing speed and reaction times, defined as a delay in response times and in the total execution of a task in the absence of a specific motor or sensory disability that would warrant such delay, the effect size was moderate, which explains the possible incidence of $\mathrm{CH}$ on these results. 5,6,11,15,16

The neurological basis responsible for processing speed is white matter; and thyroid hormones may play a critical role in the differentiation of myelin-forming cells: oligodendrocytes. In the case of $\mathrm{CH}$, myelination is qualitatively and quantitatively altered. Thus, damage in axonal myelination may result in a deceleration of processing speed and a change in the conductivity of nerve impulses. ${ }^{2}$ The mechanisms likely involved in such damage may be a reduction in the number of myelinated axons, subtle ultrastructural myelin alterations, and a lower axon diameter in the absence of thyroid hormones, given that myelination starts from a specific axon size. ${ }^{30}$

TABLE 1. Intelligence quotient of 60 children with congenital hypothyroidism early detected and treated, and 60 children from the control group (mean \pm standard deviation)

\begin{tabular}{lccccc}
\hline $\begin{array}{l}\text { Intelligence } \\
\text { quotient }\end{array}$ & \multicolumn{2}{c}{$\begin{array}{c}\text { G1 } \\
(\mathbf{n}=\mathbf{6 0})\end{array}$} & \multicolumn{2}{c}{ G2 } \\
& Mean & SD & Mean & SD & $p$ \\
\hline Total & 94.4 & 8.6 & 102.7 & 7.1 & $0.000^{*}$ \\
Performance & 85.3 & 7.2 & 98.8 & 8.2 & $0.000^{*}$ \\
Verbal & 100 & 9.1 & 104.8 & 8.4 & 0.009 \\
\hline
\end{tabular}

* Adjusted significance level $=\mathrm{p}<0.00227$.

SD: standard deviation. 
In turn, the executive function depends on an adequate myelination, which helps both in the maturation of the prefrontal cortex and its connections to cortical and subcortical areas. ${ }^{31}$

Also consistent with previous studies, our results indicate that children with $\mathrm{CH}$ have a poorer performance compared to their healthy counterparts in the semantic long-term memory tests, ${ }^{5-7,9-11,13}$ with a moderate effect size. ${ }^{2,13}$

Rovet $^{6}$ proposes that semantic memory deficit may be associated with a smaller left hippocampal volume, an essential structure for semantic memory and learning, which is dependent on thyroid hormones since the early gestation stage until early childhood. ${ }^{13}$

Children with $\mathrm{CH}$ had a poorer performance in visuospatial skills, probably in relation to the absence of thyroid hormones during the postnatal development of the primary motor cortex, which is a critical period. ${ }^{6}$

Prenatal thyroid failure may predominately affect the development of the occipital striate pathway into the superior parietal pathway, which processes spatial location, more than the development of the visual perception pathway, which may be preserved (occipital striate pathway

TABLE 2. Cognitive functions assessed in 60 children with congenital hypothyroidism and 60 children from the control group

\begin{tabular}{|c|c|c|c|c|c|c|c|}
\hline \multirow[t]{2}{*}{$\begin{array}{c}\text { Cognitive function } \\
\text { Assessed area }\end{array}$} & \multirow[t]{2}{*}{ Test } & \multicolumn{2}{|c|}{ G1 $(n=60)$} & \multicolumn{2}{|c|}{ G2 $(n=60)$} & \multirow[b]{2}{*}{$p$} & \multirow[b]{2}{*}{$\eta p$} \\
\hline & & Mean & SD & Mean & SD & & \\
\hline \multirow[t]{4}{*}{$\begin{array}{l}\text { Processing } \\
\text { speed }\end{array}$} & $\begin{array}{c}\text { WM-R } \\
\text { processing speed }\end{array}$ & 43.5 & 8.4 & 56.5 & 7.3 & $0.000^{*}$ & 0.40 \\
\hline & $\begin{array}{c}\text { WISC III } \\
\text { processing speed }\end{array}$ & 48.4 & 11.1 & 66.2 & 10.5 & $0.000^{*}$ & 0.40 \\
\hline & Rey copying speed & 272.1 & 66.5 & 214.5 & 54.2 & $0.000^{*}$ & 0.20 \\
\hline & Rey memory speed & 197.1 & 59.2 & 141 & 51.9 & $0.000^{*}$ & 0.19 \\
\hline Reaction times & CPT II & 489.8 & 95.6 & 405. & 62.9 & $0.000^{*}$ & 0.22 \\
\hline \multirow[t]{2}{*}{ Attention span } & Knox & 10.1 & 1.64 & 11.82 & 1.66 & 0.006 & 0.07 \\
\hline & Digits (direct) & 8.07 & 0.93 & 8.13 & 1.06 & 0.716 & 0.00 \\
\hline \multirow{6}{*}{$\begin{array}{l}\text { Focused, divided, } \\
\text { and sustained } \\
\text { attention }\end{array}$} & Lack of distractibility & 29.2 & 3.5 & 28.4 & 2.5 & $0.000^{*}$ & 0.01 \\
\hline & CPT II omissions & 17 & 12.9 & 9.2 & 6.8 & $0.000^{*}$ & 0.16 \\
\hline & 5 digit test & & & & & & \\
\hline & Inhibition & 57.2 & 22.1 & 35.4 & 12.5 & $0.000^{*}$ & 0.18 \\
\hline & Faces & 24.5 & 6.3 & 30.3 & 6.1 & $0.000^{*}$ & 0.22 \\
\hline & Trail Making B & 75.9 & 24.8 & 53.8 & 15.1 & $0.000^{*}$ & 0.22 \\
\hline \multirow[t]{2}{*}{ Visuoconstruction } & Object composition & 25.1 & 5.6 & 28.4 & 4.1 & $0.000^{*}$ & 0.11 \\
\hline & Cube construction & 29.3 & 9.6 & 38.1 & 10.1 & $0.000^{*}$ & 0.17 \\
\hline $\begin{array}{c}\text { Visual } \\
\text { processing }\end{array}$ & $\begin{array}{c}\text { Wechsler } \\
\text { Drawing completion }\end{array}$ & 17.70 & 2.60 & 18 & 3.03 & 0.563 & 0.00 \\
\hline \multirow[t]{2}{*}{ Long-term memory } & WM-R & 179.9 & 22.9 & 229.2 & 22.3 & $0.000^{*}$ & 0.54 \\
\hline & Information & 13.1 & 2.8 & 14.7 & 2.7 & $0.002^{*}$ & 0.07 \\
\hline \multirow[t]{4}{*}{ Cognitive flexibility } & 5 digit test & 41.5 & 14.1 & 28.2 & 10.1 & $0.000^{*}$ & 0.01 \\
\hline & Semantic & 48.95 & 9.91 & 54.9 & 11.9 & $0.000^{*}$ & 0.07 \\
\hline & Phonological & 16.15 & 15.52 & 20.6 & 4.3 & $0.000^{*}$ & 0.18 \\
\hline & Trail Making & 75.9 & 24.87 & 53.8 & 15.1 & $0.000^{*}$ & 0.22 \\
\hline
\end{tabular}

* Adjusted significance level $=\mathrm{p}<0.00227$.

$\eta p^{2}$ : effect size.

WM-R: Woodcock-Muñoz revised test;

WISC III: Wechsler Intelligence Scale for Children, third edition;

CPT II: Conners Continuous Performance Test II. 
into inferior temporal pathway). ${ }^{17}$

In his argumentative model of the syndrome of nonverbal learning disabilities, characterized by visuospatial alterations, Rourke considers that children with hypothyroidism are carriers of most of the symptoms typical of such syndrome, ${ }^{32}$ as a result of an abnormal myelinogenesis or synaptogenesis.

Consistent with Ramirez et al., ${ }^{15}$ our results confirm that patients with $\mathrm{CH}$ have a briefer attention span. ${ }^{2,3,5-7,9-11,33,34}$ In the CPT II, our group of children with $\mathrm{CH}$ had a higher number of omissions and a longer stimulus reaction time (observed in the increase occurred across the entire test). Such difference from controls was also observed in the activities where focused and divided attention was necessary. However, no differences were observed between both groups in their attention span or range when using auditory-verbal stimuli (digit test) or visuospatial stimuli (Knox test), which may be explained by the different modalities of presentation and stimulus input, and the different storage subsystems.

The prefrontal cortex has been associated with attention and, given that thyroid hormones are necessary for an ordered cerebral cortex cell distribution, thyroid hormone deficiency during the prenatal period may result in a poorer definition of frontal cortical layers, ${ }^{2,3}$ which may explain alterations in its functioning.

Cognitive flexibility consists of a mental process dependent on age, and which makes demands on inhibition processes and working memory. Cognitive flexibility was poorer among children with $\mathrm{CH}$. Coincidentally, working memory deficits have been described in these children. ${ }^{6,14,15,35}$ The prefrontal cerebral region supports both the working memory and cognitive flexibility.

Our results, translated into practice, would help us understand why parents and some teachers ask about why some children with $\mathrm{CH}$ have trouble completing their school homework, and require more control and time to finish it, and also about their tendency to become distracted or why they require more time to complete graphomotor (paper and pencil) activities. In addition, it is worth understanding that these are mild deficits, and this is evident by the fact that these children have a normal education and do not need to repeat the school year.

It is important to consider that the findings made in relation to the cognitive profile of patients with $\mathrm{CH}$ may result in a greater or lower discomfort and even go unnoticed, depending on their family and school environment, the level of parental and school demands, and the learning methodology used. Patients who develop compensatory strategies once they notice their problems achieve results in an adequate manner by skipping the difficulties they may perceive while working.

The main strength of this study is that it is representative of a population of children with and without $\mathrm{CH}$ from Buenos Aires who were selected to make up a homogeneous sample subjected to similar assessments. However, other factors inherent to $\mathrm{CH}$ should be considered in future studies to establish a relationship to neurocognitive performance.

Our findings will help to provide improved care and more accurate counseling to patients with the implementation of strategies in their school system and everyday activities or, in some cases, with health care provider interventions targeted at patient stimulation, e.g., prevention and care in relation to performance within the patient's school and family setting.

\section{REFERENCES}

1. Nuñez Almache O. Hipotiroidismo Congénito. Paediátrica 2003;5(2):93-100.

2. Arreola-Ramirez G, Barrera Reyes H, Jimenez Quiroz R, Ramírez Torres $M$, et al. Neurodesarrollo en infantes con antecedente de hipotiroidismo congénito. Perinatol Reprod Hum 2005;19(3-4):141-51.

3. Álvarez M, Caravajal F, Fernández Yero JL, Niurka C, et al. Manual de trabajo de la red nacional para la evaluación neurocognitiva del niño con hipotiroidismo congénito. Criterios para la evaluación periódica y acciones a realizar sobre el desarrollo del sistema nervioso. La Habana: UNICEF, 2004.

4. Gruñeiro de Papendieck L, Chiesa A, Prieto L. Prevención de la Discapacidad Mental y Física que originan Enfermedades Genéticas y Metabólicas inaparentes al nacimiento: Experiencia Argentina. Madrid: RealPatronato de Prevención y de Atención de Personas con Minusvalía, 1998.

5. Kooistra L, Vulsma T, Van der Meere J. An investigation of impulsivity in children with early-treated congenital hypothyroidism. Dev Neuropsychol 2004;26(2):595-610.

6. Rovet JF. Congenital Hypothyroidism: an analysis of persisting deficits and associated factors. Child Neuropsychol 2002;8(3):150-62.

7. Rovet JF, Daneman D. Congenital Hypothyroidism: a review of current diagnostic and treatment practices in relation to neuropsychologic outcome. Pediatri Drugs 2003;5(3):141-9.

8. Selva KA, Harper MD, Downs A, Blasco PA, et al. Neorudevelopmentaloutcomesincongenitalhypothyroidism: comparison of initial $\mathrm{T} 4$ dose and time to reach target $\mathrm{T} 4$ and TSH. J Pediatr 2005;147(6):775-80.

9. Joseph R. Neuro-developmental deficits in early-treated congenital hypothyroidism. Ann Acad Med Singapore 
2008;37(12 Suppl):42-3.

10. Zanin L, Gil E, De Bortoli M. Atención y Memoria su relación conla función tiroidea. Fundamentosen Humanidades 2004;5(10):31-42.

11. Zoeller R T, Rovet J. Timing of thyroid hormone action in the developing brain: clinical observation and experimental findings. J Neuroendocrinol 2004;16(10):809-18.

12. Song S, Daneman D, Rovet J. The influence of etiology and treatment factors on intellectual outcome in congenital hypothyroidism. J Dev Behav Pediatr 2001;22(6):376-84.

13. Wheeler SM, Willoughby KA, McAndreus MP, Rovet J. Hippocampal size and memory functioning with congenital hypothyroidism. JClin Endocrinol Metab 2011;96(9):e1427-34.

14. Hepworth S, Pang E, Rovet J. Word and Face Recognition in Children with Congenital Hypothyroidism: An Event-Related Potential Study. J Clin Exp Neuropsychol 2006;28(4):509-27.

15. Ramírez BY, Marchena MH. Características neuropsicológicas del niño preescolar con Hipotiroidismo Congénito en la Provincia deCienfuegos. Rev Chil Neuropsicol 2009;4(1):36-43.

16. Chiesa A, Pardo ML, Keselman A, Gruñeiro de Papendieck L. Desempeño Escolar y Evolución Madurativa en el Hipotiroidismo Congénito detectado por Pesquisa Neonatal. Rev Argent Endocrinol Metabol 2003;40(Supl):143.

17. Leneman MJ, Buchanan L, Rovet J. Where and what visuospatial processing in adolescents with congenital hypothyroidism. J Int Neuropsychol Soc 2001;7(5):556-62.

18. Wechsler D. Test de Inteligencia para Niños WISC-III. Manual. Buenos Aires: Paidós, 1997.

19. Osterrieth PA. Le test de copie d une figure complexe; contribution à létude de la perception et de la mémoire. Arch Psychol (Geneve) 1944;30:206-356.

20. Muñoz-Sandoval A, Woodcock R, McGrew K, Mather N. Batería Woodcock-Muñoz III: pruebas de habilidades cognitivas y de aprovechamiento. Itasca, IL: Riverside Publishing, 2005.

21. Conners CK. Conners Continuous Performance Test Computer Program 3.0 User's Manual. Toronto, ON:MultiHealth Systems, 1994.

22. Kirk S, McCarthy J, Kirk W. ITPA. Test de Illinois de Aptitudes Psicolinguísticas. 7.ma ed. Madrid: TEA, 2009.
23. Spreen O, Benton AL. Simulation of mental deficiency on a visual memory test. Am J Ment Defic 1963;67:909-13.

24. Bornstein RA. Construct Validity of the Knox Cube Test as a Neuropsychological Measure. J Clin Neuropsychol 1983;5(2):105-14.

25. Reitan RM, Davison LA. Clinical neuropsychology: Current status and applications. Washington, DC.: Winston, 1974.

26. Thurstone LL, Yela M. CARAS: Test de percepción de diferencias. Madrid: TEA, 1979.

27. Sedó M. Test de los cinco dígitos. Madrid: TEA, 2007.

28. Mayayo E, Puga B, Labarta JI, Ferrández Longás A. Hipotiroidismo congénito. [Accessed on: September $15^{\text {th }}$, 2016]. Available at: http:/ /www.spao.es/documentos/ reuniones/pdf-reunion-6-ficheros-82967.pdf.

29. Derksen-Lubsen G, Verkerk PH. Neuropsychologic development in early treated congenital hypothyroidism: analisis of literature data. Pediatr Res 1996;39(3):561-6.

30. Bernal Carrasco JB. Las hormonas tiroideas en el desarrollo del cerebro. En Pascual Leone AM, Medina JM. Monografía XXXIX. Acción de las hormonas a nivel cerebral. Madrid: Real Academia Nacional de Farmacia; 2010.Págs.139-60.

31. Lozano Gutiérrez A, Ostrosky Solís F. Desarrollo de las funciones ejecutivas y de la corteza prefrontal. Revista de neuropsicología, neuropediatría y neurociencias 2011;11(1): $159-72$.

32. Rourke BP, Ahmand SA, Collins DW, Hayman-Abello BA, et al. Child clinical/pediatric neuropsychology: some recent advances. Ann Rev Psychol 2002;53:309-39.

33. Oerbeck B, Sundet K, Kase B S, Heyerdahl S. Congenital hypothyroidism: no adverse effects of attention, memory and behaviour high dose thyroxine treatment on adult. Arch Dis Child 2005;90(2):132-7.

34. Olivares Torres A, Pías NC, Rodríguez C, Perez Gesen $\mathrm{C}$, et al. Atención sostenida en niños en edad escolar con hipotiroidismo congénito. Rev Cubana Endocrinol 2004;15(2). [Accessed on: April 15 $\left.{ }^{\text {th }}, 2016\right]$. Available at: http:// scielo.sld.cu/scielo.php?script=sci_arttex t\&pid=S156129532004000200002\&lng=es\&nrm=iso.

35. Hepworth SL. Verbal working memory in children with congenital hypothyroidism (microform). Toronto: Thesis - University of Toronto, 2005. 